\title{
A Review of Literature on the Gaps Model on Service Quality: A 3-Decades Period: 1985-2013
}

\author{
Aurelio G. Mauri ${ }^{1}$, Roberta Minazzi ${ }^{2} \&$ Simonetta Muccio ${ }^{1}$ \\ ${ }^{1}$ Department of Economics and Marketing, IULM University, Italy \\ ${ }^{2}$ Department of Law, Economics and Culture, University of Insubria, Italy \\ Correspondence: Aurelio G. Mauri, Department of Economics and Marketing, IULM University, Italy. E-mail: \\ aurelio.mauri@iulm.it
}

Received: September 12, 2013

Accepted: October 10, 2013

Online Published: November 22, 2013

doi: 10.5539/ibr.v6n12p134

URL: http://dx.doi.org/10.5539/ibr.v6n12p134

\begin{abstract}
The study aims to contribute to the research on service quality, analyzing almost 30 years of research on the Gaps Model proposed by Parasuraman, Zeithaml and Berry in the 1980s. A literature review has been conducted from 1985 to 2013 with the purpose of underlining the model evolution and its criticisms. Major international academic databases have been consulted.

On this basis the paper summarizes some theoretical-conceptual and methodological-operational critical aspects identified by scholars who analyzed and applied the model and the scale. Despite that, the Gaps Model and the SERVQUAL scale are still the most used instruments to study service quality in marketing literature.

The analysis allows to identify interesting points for future research on the topic of service quality. The conceptual framework presented in the paper does not include any empirical research that could be eventually implemented to validate the findings.
\end{abstract}

Keywords: gaps model, SERVQUAL, service quality

\section{Introduction}

The debate on service quality, wherein marketing experts have been involved during the last decades, has led to the elaboration of numerous analytic approaches and descriptive models. Among them, the Gaps Model, developed together with the SERVQUAL scale by Parasuraman, Zeithaml and Berry (1985), is still the most used.

The Gaps Model, based on the expectation-confirmation theory (Oliver, 1980), illustrates how consumers assess quality, and takes into account the factors that contribute to determine quality in its various connotations. After the first publications at the end of the Eighties, the debate on Service Quality based on the Gaps Model has concerned a growing number of scholars. In fact, in the following years several studies tried to apply the theoretical concepts of the Gaps Model by means of the SERVQUAL scale to different services sectors and to different geographical areas.

Nevertheless, the paradigm proposed by the Gaps Model has encountered some criticisms. In particular, a few scholars consider the comparison between expectations and perceptions related to a specific transaction as a limit of the construct.

\section{The Literature Review: Research Methodology}

Afterwards the publication of the first articles by Parasuraman, Zeithaml and Berry $(1985 ; 1988 ; 1991 ; 1993)$, a growing number of scholars have fostered a debate on the theoretical fundamentals of the Gaps Model, as well as on the constructs related to the quality evaluations of the services delivered, and the meaningfulness of the adopted measuring ranges. In the following years some conceptual papers were corroborated by several empirical researches aimed to verify the actual applicability of the Gaps Model in different services sectors, and in various geographical contexts. This research effort elicited a huge corpus of academic literature that seems to have found a new vitality in the last quinquennium. This widespread interest in the Gaps Model and SERVQUAL is an evidence both of the concern that even nowadays this model engenders in the academics as well as in the practitioners, and of its broad practical applicability. 
In order to examine the evolution of the academic literature on this topic, and to identify the most relevant contributions in highlighting the potentialities and the limits of the model, the present article tries to offer a literature review based on the following criteria of analysis:

- database: ISI Web of Science;

- $\quad$ period of publication: from 1990 to June 2013;

- type of publication: referred article;

- research keywords: "SERVQUAL", and "service quality" + "Gap" or "Gaps";

- research area: conceptual;

- the specific research area of the article.

Table 1. The steps of the literature review on ISI Web of Science (January 1985-June 2013)

\begin{tabular}{|c|c|c|c|c|c|}
\hline & $\begin{array}{c}\text { ISI overall } \\
\text { research by } \\
\text { keywords }\end{array}$ & $\begin{array}{l}\text { ISI first } \\
\text { selection }\end{array}$ & $\begin{array}{l}\text { ISI final } \\
\text { selection }\end{array}$ & $\begin{array}{c}\text { Berry, Parasuraman, } \\
\text { Zeithaml articles }\end{array}$ & $\begin{array}{c}\text { Total selected } \\
\text { articles by year }\end{array}$ \\
\hline before 1990 & - & - & - & 6 & 6 \\
\hline 1990 & 1 & 1 & 1 & 1 & 2 \\
\hline 1991 & 1 & 1 & 1 & 2 & 3 \\
\hline 1992 & 2 & 2 & 2 & - & 2 \\
\hline 1993 & 4 & 2 & 2 & 3 & 5 \\
\hline 1994 & 10 & 4 & 3 & 2 & 5 \\
\hline 1995 & 7 & - & - & - & - \\
\hline 1996 & 12 & 4 & 1 & 1 & 2 \\
\hline 1997 & 20 & 6 & 1 & - & 1 \\
\hline 1998 & 18 & 3 & 2 & 1 & 3 \\
\hline 1999 & 17 & 3 & 2 & - & 2 \\
\hline 2000 & 28 & 8 & 6 & 1 & 7 \\
\hline 2001 & 27 & 4 & 3 & 1 & 4 \\
\hline 2002 & 22 & 2 & 2 & 1 & 3 \\
\hline 2003 & 17 & 1 & - & - & - \\
\hline 2004 & 24 & 3 & 1 & - & 1 \\
\hline 2005 & 21 & 2 & 1 & 1 & 2 \\
\hline 2006 & 26 & 1 & - & - & - \\
\hline 2007 & 29 & 5 & 4 & - & 4 \\
\hline 2008 & 30 & - & - & - & - \\
\hline 2009 & 73 & 6 & 3 & - & 3 \\
\hline 2010 & 66 & 6 & 2 & 1 & 3 \\
\hline 2011 & 47 & 5 & 3 & - & 3 \\
\hline 2012 & 36 & 3 & 1 & - & 1 \\
\hline 2013 & 12 & - & - & - & - \\
\hline Total articles & 550 & 72 & 41 & 21 & 53 \\
\hline
\end{tabular}


By means of a keyword research into the ISI Web of Science database, we have found 550 referred articles published from 1990 to June 2013 (Table 1). A further selection of identified contributions, based on the title and on the related abstract, led to a shorter list of 72 conceptual articles which, although sometimes sustained by empirical research, presents a significant theoretical approach in line with the main purpose of this paper. After a thorough analysis of the contents, the first list of selected articles was further refined in a shorter set of 41 contributions which were used as the cognitive base of the literature review presented in the next pages. The literature published by the original authors of the Gaps Model jointly, as well as individually or with other academics, was object of an ad hoc review from which resulted a set of 21 articles printed between 1985 and 2013. This specific research aimed to guarantee an interpretation as relevant and fitting as possible of the original idea of Parasuraman, Zeithaml and Berry, and of its evolution following up the academic debate.

Moreover, with the purpose to rectify the limits that a bibliographic research by keywords based only on international databases of referred articles could present, the final list of 41 articles was integrated by a wider analysis of the indexed contribution on Google Scholar. This further analysis allowed to enlarge the literature review, adding some relevant articles published from 1985 to 1990. Finally, the theoretical framework was completed by some valuable contributions from more extensive topics as marketing, and service quality which could offer interesting stimuli for a re-examination of the Gaps Model in both a competitive, and a communicational way. Altogether those final steps of the analysis added to the original database selected from ISI Web of Science further 22 articles plus 18 mixed contributions (books, chapters in books, and papers).

\section{The Gaps Model}

The Gaps Model was first published in 1985 and then further modified and developed by the same authors (Parasuraman, Zeithaml \& Berry, 1988; 1991; 1994a; 1994b; Parasuraman, Berry \& Zeithaml, 1990; 1991; 1993). The model, based on the expectation-confirmation theory (Oliver, 1980; 1993), illustrates how consumers assess quality, taking into account the factors that contribute to determine quality in its various connotations: quality expected by customers, quality offered by firms, quality perceived by users after the service consumption Stemming from the definition of quality as the capability to satisfy consumer expectations, the Gaps Model aims to identify the possible causes for a gap between expected quality and perceived quality (Gap 5). The model conceptualizes key concepts, strategies and decisions which are essential for the quality offer according to a sequence which starts from the consumer, identifies necessary actions for the firm to plan and offer a service, and go back to the consumer in the hub of the model: the comparison between expectations and perceptions.

According to the above-mentioned authors, service quality is a multidimensional concept, assessed and perceived by consumers according to a set of essential components, originally grouped in ten categories (1985) and then in five levels (1988):

- tangible aspects: aspects of physical facilities, equipment and personnel;

- reliability: capability of the firm to perform the promised service in a careful and accurate manner;

- responsiveness: willingness of the firm to help customers and perform the service promptly;

- assurance: competence and politeness of the personnel, capability to inspire confidence;

- empathy: personalized assistance that the firm conveys to its customers.

In 1988 the authors outlined a scale named SERVQUAL to measure possible gaps (Parasuraman et al., 1988). The scale consists of 44 questions based on the five above-mentioned components and given out to customers directly as questionnaires. The first 22 -item group surveys customer expectations whereas the second 22 -item group deals with customer perceptions of the service consumption. Customers are asked to express an evaluation for each item ranging from 1 (strongly disagree) to 7 (strongly agree).

Figure 1 shows the original Gaps Model structure $(1985 ; 1988)$ updated with the changes of the part related to customer expectations made by the authors in 1993. In 1994 the model was revised (number and wording of items, measurement scale) on the strength of different authors' criticisms (see next paragraph) and considering the more detailed definition of expected service outlined in 1993.

The model identifies 5 gaps, of which the "Customer Gap" (Gap 5) is the main one as it identifies the discrepancy between expectations and actual perception of service quality by the customer. In particular, according to the model, such deviation is to be ascribed to four possible gaps which may manifest themselves in the perception of service quality by the firm management and in the activities connected with its delivery.

Gap 1 occurs when the management wrongly assesses customer quality expectations as a consequence of the lack of market research or the lack of upward communication within the firm.

Gap 2 deals with the discrepancy between management perception of customer expectations and the settlement 


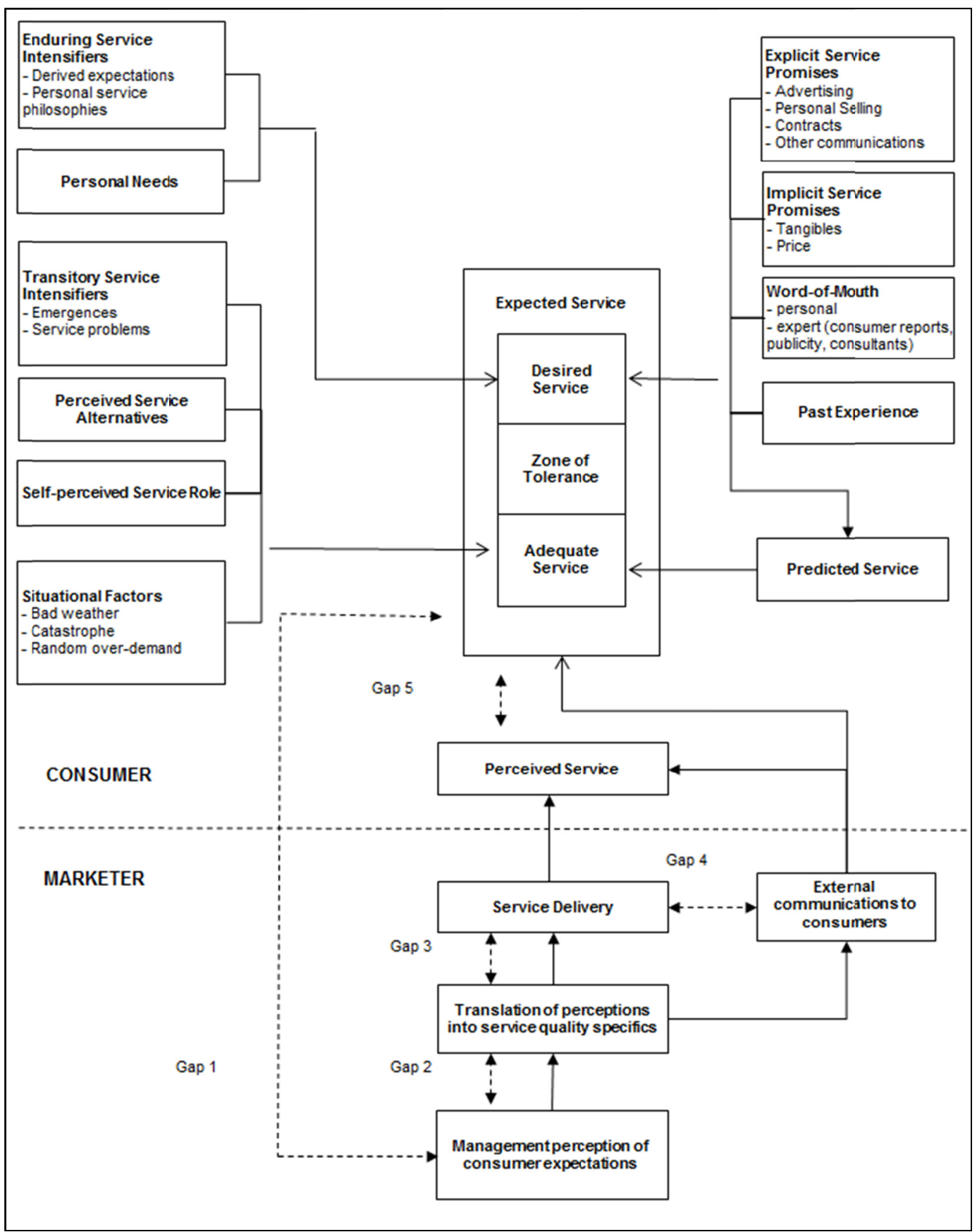

Figure 1. The Gaps Model with the changes of the authors, adapted from Parasuraman, Zeithaml and Berry (1985) and Zeithaml, Berry and Parasuraman (1993)

of appropriate standards of service quality. This Gap may derive from the management inability/indifference to put into effect what learnt from the study of customer expectations about appropriate service standards (Note 1).

Gap 3 occurs when there is a discrepancy between service quality standards and firm personnel performance in the service delivery as a consequence of a lack of appropriateness of both the technology and the operating systems, which derive from organizational problems or related to the downward communication.

Gap 4 occurs when quality characteristics conveyed to customers through external communication (i.e., advertisements, personal selling, etc.) do not match those of the service delivered. Basically, the firm promises a service which will not correspond to what actually will be delivered. Generally, this Gap is the result of inappropriate horizontal communication among divisions and inconsistent external communication.

According to this model, the firms that aim to remove the "Customer Gap" have to strive for a reduction of the 
"Marketer Gap" from 1 to 4.

\section{The Model Development and the Related Doctrinal Debate}

The development of the Gaps Model has generated an intense and rich debate among scholars. Indeed, many authors point out both some theoretical-conceptual and methodological-operational critical aspects to be considered. Reviews of the contributions to this subject have been carried out by Buttle (1996), Coulthard (2004), Ladhari (2009).

\subsection{Theoretical-Conceptual Objections to the Gaps Model and to the SERVQUAL Scale}

Specifically, the theoretical-conceptual objections raised to the model relate to the following aspects.

\subsubsection{Use of the Expectation-Confirmation Theory}

Some authors cast doubts on the analysis of expectations and perceptions as two different entities, thus preferring a unified approach which studies perceptions as the result of the cognitive process of the consumer. Indeed, they affirm that expectations are based on bias about the service which are difficult to be construed and which may change with the actual experience and the familiarity of the customer about the service (Carman, 1990; Babakus \& Boller, 1992; Webb, 2000). In particular, in 1992 Cronin and Taylor developed the SERVPERF scale based on the belief that the comparison between perceptions and expectations occurs automatically in the consumers' mind (Carman, 1990; Cronin \& Taylor, 1992; 1994; Brown, Churchill \& Peter, 1993; Teas, 1993; Grönroos, 2007). In addition, according to some authors, a double measurement is worthless as in the majority of cases expectations exceed actual perceptions (Brown et al., 1993). Thus, the SERVPERF scale does not take into consideration the set of items referred to expectations and simplifies the analysis to a mere survey of perception assessment. The effectiveness of the approach based on perceptions, that has been supported by numerous authors (Cronin \& Taylor, 1992; 1994; Boulding, Kalra, Staelin \& Zeithaml, 1993; Dion, Javalgi \& Dilorenzo-Aiss, 1998; Caruana, Ewing \& Ramaseshan, 2000; Brady, Cronin \& Brand, 2002), does not want to underestimate the important role of expectations, but to shed light on the prominent role of perceptions in affecting service quality (Cronin \& Taylor, 1994). However, other attempts to apply the SERVPERF scale demonstrate the necessity to adapt the considered quality dimensions to the business investigated (Taylor \& Cronin, 1994; Fogarty, Catts \& Forlin, 2000). With regard to the predominance of perceptions, in 2004 Parasuraman, Zeithaml and Berry reaffirmed their position and confirmed that the comparison between expectations and perceptions of performance allows to make a long term assessment and to gain more information.

Which of the two scales is the most appropriate for quality measurement is still debated by experts. Recent studies have demonstrated that both models have a predictive capability with reference to service quality; this capability varies with the context and the objectives of the analysis and it presents both strong and weak points depending on the case (Carrillat, Jaramillo \& Mulki, 2007; Landrum, Prybutok \& Zhang, 2007; Brandon-Jones $\&$ Silvestro, 2010). Approaches which aim to reconcile different positions (Brady \& Cronin, 2001) have not diverted attention from the debate between the above-mentioned two models.

\subsubsection{Ambiguity of the Concept of Expectations}

The concept of expectations - that was at the basis of the model in 1985-was further clarified by SERVQUAL authors in 1993 when its dimensions were detailed: desired service and adequate service (Zeithaml et al., 1993). These two, together with the expected service, affect the perceived service. Nevertheless, even if these concepts may be interpreted in different ways, in literature they are used as synonyms sometimes (Teas, 1993; 1994).

\subsubsection{Ambiguity of the Concepts of Perceived Service Quality and Customer Satisfaction}

The use of the expectation-confirmation theory, generally employed in the study of customer satisfaction, has raised further critical comments. In particular, according to Cronin and Taylor $(1992 ; 1994)$ the customer satisfaction conceptualization as preceding and forerunning the perceived service quality is not appropriate. Indeed, literature on this theme points out that the main trend is that of considering service quality an antecedent and a component of customer satisfaction. Later, Parasuraman et al. (1994a) have partially agreed with this position, but have considered it an open issue. In the most recent publications, some of the original authors support this frame of reference and identify the factors which link the concepts of quality and customer satisfaction in the service sector (Zeithaml, Bitner \& Gremler, 2012).

\subsubsection{Competition, Expectations and Perceptions}

It is widely known that market relations are fundamental for expectations and perception development, as well as for the identification of quality standards and for the firm actual performance (Erickson \& Johansson, 1985; 
Martin, 1986; Zeithaml, 1988; Brucks, Zeithaml \& Naylor, 2000). Competition was not contemplated in the original Gaps Model, but was then introduced by the authors in a revision in 1993, with a limited role of "perceived service alternatives". In the model, such alternatives are deemed to be able to exert influence on the "adequate service" component of the "expected service", but not on the "desired service". As for the customer assessment processes, the model does not reckon that competitor marketing communication plays a role. According to recent studies competitors' offers do have a significant influence also on the "desired service" and their communication does play a major influence on customers' perceptions (Mauri, Minazzi \& Muccio, 2012).

\subsubsection{Minor Role of Communication}

In the Gaps Model, as for both external and internal communication, it is always the firm to be in charge of communication flows (firm-controlled information). However, this does not exclude other possible information sources to which the customer has or can have access to. In fact, two main informative sources are also considered: interpersonal sources, which are governed by the customer, and neutral or independent sources (Cox, 1967), as widely experienced in the hospitality sector. These additional sources, which are not considered by the model, can make their contribution to expectation development and affect directly quality perceptions and the level of satisfaction accordingly (Mauri et al., 2012).

\subsection{Methodological-Operational Objections to the Gaps Model and to the SERVQUAL Model}

A second group of methodological-operational objections raised against the model are outlined here below.

\subsubsection{Dimensions and Operational Applicability of the Model to Different Sectors}

SERVQUAL is presented by its authors as a measurement method of quality which can be applied easily to the different service sectors. However, some attempts to implement the model to areas different from the original ones have presented problems, especially in respect of the management of the five dimensions, the number and the wording of questions and the scale used. Due to these difficulties, scholars of the service sector have chosen to adapt dimensions and items (by adding ones or removing others) according to the specific context where the SERVQUAL scale is applied (Carman, 1990; Finn \& Lamb, 1991; Brown et al., 1993; Dabholkar, 2000; Mels, Boshoff \& Nel, 1997; Llosa, Chandon \& Orsingher, 1998; Sureshchandar, Chandrasekharan \& Kamalanabhan, 2001; Luk \& Layton, 2007; Saravanan \& Rao, 2007; Sanchez-Hernandez, Martinez-Tur, Peiro \& Ramos, 2009; Ravichandran, Mani, Kumar \& Prabhakaran, 2010). In addition, what cannot be underestimated is the possibility that anomalies occur when carrying out the analysis in a different culture: in this case too, according to various studies, it is necessary to make some adjustments to the model, the methodology and the items (Herk, Poortinga \& Verhallen, 2005; Carrillat, 2007; Ladhari, 2009).

With reference to these remarks, Parasuraman, Zeithaml and Berry confirm their original position and recommend making slight adjustments to the 22 items in order to keep the model working, even though they identify a sort of overlapping of the five dimensions of the model (Parasuraman et al., 1991; 1994a). It still remains an open debate; for example some recent studies have just confirmed that the dimensions of the SERVQUAL scale are applicable in several sectors (Setò-Pamies, 2012).

\subsubsection{Perceptions-Expectations Assessment}

The SERVQUAL Model is based on the analysis of quality assessment by a group of respondents who have experienced the service in the previous three months. This means that the request of perceptions and expectations evaluation comes at the same time, after the actual experience of the customer. This operation affects undoubtedly expectations, which can change, even subconsciously, after the service consumption. A survey of expectations assessment before the service delivery may have contributed to a more realistic picture (Carman, 1990; Grönroos, 1993).

\subsubsection{Items Wording}

The wording of questions have been criticized for the use of the terminology based on 'should expectations' which may produce very high expectations assessment and, therefore, unrealistic ones (Carman, 1990; Brown et al., 1993). In addition, in order for the model to be more adaptable to other services, it may be convenient to revise the terminology to make it more specific and more understandable by the customers of specific businesses (Carman, 1990; Llosa et al., 1998).

Some of these problems were brought to light by the authors themselves, who then modified the model in 1991 and 1994 with an approach oriented to assess the expectations level related to the best practices of the sector: "Excellent telephone companies have up-to-date equipment" (Parasuraman et al., 1991; 1994b). The use of both positive and negative wording, which according to Babakus and Boller (1992) can influence respondents 
judgments, has been revised and the use of positive wording preferred and made uniform. In addition, question wording and length have been modified in order to be less redundant and more easily understood (Parasuraman et al., 1994b).

\subsubsection{Measurement Scale}

The SERVQUAL uses a seven-point Likert scale, which have two main problematic points: the lack of the option "Don't know" and the number of values. As regards the first aspect, it has to be considered that consumers who do not have the necessary experience of the product tend not to reply or to choose a central value (4 in case of a 7 value scale), as they do not find a proper answer. This may distort data and lead to interpretation problems. With regard to the second aspect, the topic of the proper number of scale values to be used is particularly controversial and scholars who have applied the model to other sectors have made changes to this aspect too (Carman, 1990). Finally, the data analysis procedures have been sometimes considered not apposite or improvable from the point of view of the statistical approach (Buttle, 1996).

\subsubsection{The Static Nature of the Models}

Recently, some scholars have shed light on the need to use a less static approach in order to stick to the dynamic nature of the service sector and of the concept of quality (McCollin, Ograjensek, Goeb \& Ahlemeyer-Stubbe, 2011). Consumer expectations and perceptions change constantly and the quality assessment, expectations and perceptions vary according to the meaning that consumers give to their experience (Schembri \& Sandberg, 2011). These observations (Anderson \& Fornell, 1994; Johnson, Anderson \& Fornell, 1995; Mauri et al., 2012) are grounded on the assumption that individual attitudes and behaviors can be directly related to particular situations to the extent of hindering the generalizability of research into them (Zeithaml, Berry \& Parasuraman, 1996). To be concise, the Gaps Model reveals to be focused on fixed dimensions and on a "tight" and "static" reasoning which does not contemplate any difference among customer segments, stakeholders as a whole, nor consider the role of communication and of the relations which can be activated in the processes of expectations development and satisfaction assessments. This is due to a usual simplification occurred in research into the Gaps Model, which was carried out focusing on the analysis of service features, as well as multiple quality dimensions, with the purpose of identifying standardized dimensions with universal predictive capability (Schembri \& Sandberg, 2002; 2003).

\section{Conclusions}

The article is a conceptual paper and the main objective is to understand the state of art of the research on service quality measurement studies identifying future paths of study. Critical literature review shows how the Gaps Model has been taken as a starting point for a number of theoretical and practical studies which have gone beyond American and European boundaries to spread all-over continents. After almost thirty years from its presentation, the Gaps Model still raises interest among scholars. In these respects, it is interesting to note that the wide-ranging literature on marketing covers both presentations of the model in its original version and copious revisions, adjustments and applications of the same, yet without overturning its theoretical principles.

Notwithstanding the fact that there are numerous attempts to develop new quality measurement models and/or scales in various sectors (Lovelock, 1994; Bennington \& Cummane, 1998; Candido \& Morris, 2000; Brady \& Cronin, 2001; Luk \& Layton, 2002; Getty \& Getty, 2003; Chiu \& Lin, 2004; Chatterjee \& Chatterjee, 2005; Gupta, McDaniel \& Herath, 2005; Urban, 2009; Baccarani, Ugolini \& Bonfanti, 2010; Durvasula, Lysonshi \& Madhavi, 2011; Calabrese \& Scoglio, 2012), the Gaps Model remains a reference point in literature about service quality. In addition, new technologies and the increasing awareness of the dynamic nature of services underline the need for an updated analytical perspective which take into consideration the crucial factors for the company evolution in uncertain and more competitive enviroments (Macdonald, Wilson, Martinez \& Toosi, 2011; van der Wiele, van Iwaarden, Williams \& Eldridge, 2011).

The strengths of the Gaps Model certainly lie in its relative simplicity, in the linearity of its outline and in the rationality of the firm actions, which determine its intelligibility and its communicative force. It is also our view that these same strong points may nonetheless pose a challenge to the model: it is evident that the analytical-reductionist approach on which it is developed fragments reality into separate elements leaving behind the systemic nature of the firm, which, in actual facts, is a system immersed in the environment.

Reflections arisen from conducting this research lead us to look with interest to every innovative contribution intended to develop a new approach aimed to challenge the traditional conception of unidirectional and linear cause-effect relation among the elements of the model. An approach grounded on a systemic logic characterized by mutual relations and circular interactions. The main pillar of this approach is the recognition of the firm as a 
subject which is not isolated but operates also among cooperative and competitive relations with other actors who are connected by various resource and communication flows.

Further research developments may focus on the role of price and on the relation between service quality and customer satisfaction. Referring to price, it is our opinion that its role should be analyzed in a more extensive way, considering its impact on customer expectations and purchase behavior, its relevance for quality and value assessments, in light of the employment of revenue management techniques, which are widespread in the service sector. Discussing on the relation between quality and customer satisfaction, it is remarked that the determiners of these two concepts and the relation concerning them are still object of ongoing interesting investigations.

\section{References}

Anderson, E., \& Fornell, C. (1994). A customer satisfaction research prospectus. In Rust, R. T., \& Oliver, R. L. (Eds.), Service quality: New directions in theory and practice (pp. 241-268). Sage, Thousand Oaks. http://dx.doi.org/10.4135/9781452229102.n11

Babakus, E., \& Boller, G. W. (1992). An empirical assessment of the SERVQUAL scale. Journal of Business Research, 24(3), 253-268. http://dx.doi.org/10.1016/0148-2963(92)90022-4

Baccarani, C., Ugolini, M., \& Bonfanti, A. (2010). A conceptual service quality map: the value of a wide opened perspective, 13th Toulon-Verona Conference "Excellence in Services", 2-4 September 2010, Coimbra, Portugal.

Bennington, L., \& Cummane, J. (1998). Measuring service quality: a hybrid methodology. Total Quality Management, 9(6), 395-405. http://dx.doi.org/10.1080/0954412988343

Boulding, W., Kalra, A., Staelin, R., \& Zeithaml, V. A. (1993). A Dynamic Process Model of Service Quality: From Expectations to Behavioral Intentions. Journal of Marketing Research, 30(1), 7-27. http://dx.doi.org/10.2307/3172510

Brady, M. K., \& Cronin, J. J. (2001). Some new thoughts on conceptualizing perceived service quality: A hierarchical approach. Journal of Marketing, 65(3), 34-49. http://dx.doi.org/10.1509/jmkg.65.3.34.18334

Brady, M. K., Cronin, J. J., \& Brand, R. R. (2002). Performance — only measurement of service quality: a replication and extension. Journal of Business Research, 55(1), 17-31. http://dx.doi.org/10.1016/S0148-2963(00)00171-5

Brandon, J. A., \& Silvestro, R. (2010). Measuring Internal Service Quality: Comparing the Gap-Based and Perceptions-Only Approaches. International Journal of Operations \& Production Management, 30(12), 1291-1318. http://dx.doi.org/10.1108/01443571011094271

Brown, T. J., Churchill, G. A. Jr., \& Peter, P. J. (1993). Improving the measurement of service quality. Journal of Retailing, 68(1), 127-139. http://dx.doi.org/10.1016/S0022-4359(05)80006-5

Brucks, M., Zeithaml, V. A., \& Naylor, G. (2000). Price and Brand Name as Indicators of Quality Dimensions for Consumer Durables. Journal of the Academy of Marketing Science, 28(3), 359-374. http://dx.doi.org/10.1177/0092070300283005

Buttle, F. (1996). SERVQUAL: review, critique, research agenda. European Journal of Marketing, 30(1), 8-32. http://dx.doi.org/10.1108/03090569610105762

Calabrese, A., \& Scoglio, F. (2012). Reframing the past: a new approach in service quality assessment. Total Quality Management \& Business Excellence, 23(11), 1329-1343. http://dx.doi.org/10.1080/14783363.2012.733259

Candido, C. J. F., \& Morris, D. S. (2000). Charting service quality Gaps. Total Quality Management, 11(4-6), 463-472. http://dx.doi.org/10.1080/09544120050007779

Carman, J. M. (1990). Consumers' perceptions of service quality: an assessment of the SERVQUAL dimensions. Journal of Retailing, 66(1), 33-55.

Carrillat, F. A., Jaramillo, F., \& Mulki, J. P. (2007). The validity of the SERVQUAL and SERVPERF scales-A meta-analytic view of 17 years of research across five continents. International Journal of Service Industry Management, 18(5), 472-490. http://dx.doi.org/10.1108/09564230710826250

Caruana, A., Ewing, M. T., \& Ramaseshan, B. (2000). Assessment of the three-column format SERVQUAL: an experimental approach. Journal of Business Research, 49(1), 57-65. http://dx.doi.org/10.1016/S0148-2963(98)00119-2 
Chatterjee, S., \& Chatterjee, A. (2005). Prioritization of service quality parameters based on ordinal responses. Total quality management \& Business Excellence, 16(4), 477-489. http://dx.doi.org/10.1080/14783360500078482

Chiu, H. C., \& Lin, N. P. (2004). A service quality measurement derived from the theory of needs. The Service Industries Journal, 24(1), 187-204. http://dx.doi.org/10.1080/02642060412331301202

Coulthard, L. J. M. (2004). Measuring service quality. A review and critique of research using SERVQUAL. International Journal of Market Research, 46(4), 479-497.

Cox, D. F. (1967). Risk taking and information handling in consumer behavior. Boston: Boston University Press.

Cronin, J. J., \& Taylor, S. A. (1992). Measuring service quality: a re-examination of extension. Journal of Marketing, 56(3), 55-68. http://dx.doi.org/10.2307/1252296

Cronin, J. J., \& Taylor, S. A. (1994). SERVPERF versus SERVQUAL: reconciling performance-based and perceptions-minus-expectations measurement of service quality. Journal of Marketing, 58(1), 125-131. http://dx.doi.org/10.2307/1252256

Dabholkar, P. A., Shepherd, C. D., \& Thorpe, D. I. (2000). A comprehensive framework for service quality: An investigation of critical conceptual and measurement issues through a longitudinal study. Journal of Retailing, 76(2), 139-173. http://dx.doi.org/10.1016/S0022-4359(00)00029-4

Dion, P. A., Javalgi, R., \& Dilorenzo, A, J. (1998). An Empirical Assessment of the Zeithaml, Berry and Parasuraman Service Expectations Model. Service Industries Journal, 18(4), 66-86. http://dx.doi.org/10.1080/02642069800000042

Durvasula, S., Lysonshi, S., \& Madhavi, A. D. (2011). Beyond service attributes: do personal values matter? Journal of Service Marketing, 25(1), 33-45. http://dx.doi.org/10.1108/08876041111107041

Erickson, G. M., \& Johansson, J. K. (1985). The Role of Price in Multi-Attribute Product Evaluations, Journal of Consumer Research, 12(2), 195-199. http://dx.doi.org/10.1086/208508

Finn, D. W., \& Lamb, C. W. (1991). An evaluation of the SERVQUAL scales in a retail setting. Advances in Consumer Research, 18(4), 483-490.

Fogarty, G., Catts, R., \& Forlin, C. (2000). Measuring service quality with SERVPERF. Journal of Outcome Measurement, 4(1), 425-447.

Getty, J. M., \& Getty, R. L. (2003). Lodging Quality Index (LQI): assessing customers' perception of quality delivery. International Journal of Contemporary Hospitality Management, 15(2), 94-104. http://dx.doi.org/10.1108/09596110310462940

Grönroos, C. (2007). Service management and marketing. Chichester: Wiley.

Grönroos, C. (1993). Toward a third phase in service quality research. In Swartz, T. A., Bowen, D. E., \& Brown, S.W. (Eds.), Advances in Services Marketing and Management: Research and Practice (Vol. 2, pp. 49-64). Greenwich: JAI Press.

Gupta, A., McDaniel, J. C., \& Herath, S. K. (2005). Quality management in service firms: sustaining structures of total quality service. Managing Service Quality, 15(4), 389-402. http://dx.doi.org/10.1108/09604520510606853

Herk, H. V., Poortinga, Y. H., \& Verhallen, T. M. M. (2005). Equivalence of survey data: relevance for international marketing. European Journal of Marketing, 38(3-4), 351-364. http://dx.doi.org/10.1108/03090560510581818

Johnson, M. D., Anderson, E. W., \& Fornell, C. (1995). Rational and Adaptive Performance Expectations in a Customer Satisfaction Framework. Journal of Consumer Research, 21(4), 695-707. http://dx.doi.org/10.1086/209428

Ladhari, R. (2009). A review of twenty years of SERVQUAL research. International Journal of Quality and Service Sciences, 1(2), 172-198. http://dx.doi.org/10.1108/17566690910971445

Landrum, H., Prybutok, V. R., \& Zhang, X. (2007). A comparison of Magal's service quality instrument with SERVPERF. Information \& Management, 44(1), 104-113. http://dx.doi.org/10.1016/j.im.2006.11.002

Llosa, S., Chandon, J. L., \& Orsingher, C. (1998). An empirical study of SERVQUAL's dimensionality. Service Industries Journal, 18(2), 16-44. http://dx.doi.org/10.1080/02642069800000017 
Lovelock, C. (1994). Product Plus: How Product + Service = Competitive Advantage. New York: McGraw-Hill.

Luk, S. T. K., \& Layton, R. (2002). Perception Gaps in customer expectations: Managers versus service providers and customers. Service Industries Journal, 22(2), 109-128. http://dx.doi.org/10.1080/714005073

Macdonald, M. K., Wilson, H., Martinez, V., \& Toosi, A. (2011). Assessing value-in use: a conceptual framework and exploratory study. Industrial Marketing Management, 40, 671-682. http://dx.doi.org/10.1016/j.indmarman.2011.05.006

Martin, R. E. (1986). On judging quality by price: price dependent expectations, not price dependent preferences. Southern Economic Journal, 52(3), 665-672. http://dx.doi.org/10.2307/1059265

Mauri, A. G., Minazzi, R., \& Muccio, S. (2012). Comunicazione e competizione, i due elementi per la reinterpretazione del modello dei gap sulla qualità dei servizi. Sinergie, 89(September-December), 231254.

McCollin, C., Ograjensek, I., Goeb, R., \& Ahlemeyer, S. A. (2011). SERVQUAL and the Process Improvement Challenge. Quality and Reliability Engineering International, 27(5), 705-718. http://dx.doi.org/10.1002/qre.1234

Mels, G., Boshoff, C., \& Nel, D. (1997). The dimensions of service quality: The original European perspective revisited. Service Industries Journal, 17(1), 173-189. http://dx.doi.org/10.1080/02642069700000009

Oliver, R. L. (1980). A cognitive model of the antecedents and consequences of satisfaction decision. Journal of Marketing Research, 17(11), 460-469. http://dx.doi.org/10.2307/3150499

Oliver, R. L. (1993). A conceptual model of service quality and service satisfaction: compatible goals, different concepts. In Swartz, T. A., Bowen, D. E., \& Brown, S. W. (Eds.), Advances in Services Marketing and Management: Research and Practice (Vol. 2, pp. 65-85). Greenwich: JAI Press.

Parasuraman, A., Berry, L. L., \& Zeithaml, V. A. (1990). Guidelines for conducting Service quality research. Marketing Research, 2(4), 34-44.

Parasuraman, A., Berry, L. L., \& Zeithaml, V. A. (1991). Perceived service quality as a customer-based performance measure: An empirical examination of organizational barriers using an extended service quality model. Human Resource Management, 30(3), 335-364. http://dx.doi.org/10.1002/hrm.3930300304

Parasuraman, A., Berry, L. L., \& Zeithaml, V. A. (1993). More on improving service quality. Journal of Retailing, 69(1), 140-147. http://dx.doi.org/10.1016/S0022-4359(05)80007-7

Parasuraman, A., Zeithaml, V. A., \& Berry, L. (1985). A conceptual model of service quality and its implications for future research. Journal of Marketing, 49(4), 41-50. http://dx.doi.org/10.2307/1251430

Parasuraman, A., Zeithaml, V. A., \& Berry, L. L. (1988). SERVQUAL: a multiple-item scale for measuring consumer perception of service quality. Journal of Retailing, 64(1), 12-40.

Parasuraman, A., Zeithaml, V. A., \& Berry, L. L. (1991). Refinement and reassessment of the SERVQUAL scale. Journal of Retailing, 67(4), 420-451.

Parasuraman, A., Zeithaml, V. A., \& Berry, L. L. (1994a). Alternative scales for measuring service quality: a comparative assessment based on psychometric and diagnostic criteria. Journal of Retailing, 70(3), 201230. http://dx.doi.org/10.1016/0022-4359(94)90033-7

Parasuraman, A., Zeithaml, V. A., \& Berry, L. L. (1994b). Reassessment of expectations as a comparison standard in measuring service quality: implications for further research. Journal of Marketing, 58(1), 111124. http://dx.doi.org/10.2307/1252255

Ravichandran, Tamil, M. B., Arun, K. S., \& Prabhakaran, S. (2010). Influence of Service Quality on Customer Satisfaction Application of SERVQUAL Model. International Journal of Business \& Management, 5(4), $117-124$.

Sanchez, H. R. M., Martinez, T. V., Peiro, J. M., \& Ramos, J. (2009). Testing a hierarchical and integrated model of quality in the service sector: functional, relational, and tangible dimensions. Total Quality Management \& Business Excellence, 20(11), 1173-1188. http://dx.doi.org/10.1080/14783360903247577

Saravanan, R., \& Rao, K. S. P. (2007). Measurement of service quality from the customer's perspective-An empirical study. Total Quality Management \& Business Excellence, 18(3-4), 435-449. http://dx.doi.org/10.1080/14783360701231872

Schembri, S., \& Sandberg, J. (2002). Service quality and the consumer's experience: Towards an interpretive 
approach. Marketing Theory, 2(2), 189-205. http://dx.doi.org/10.1177/147059310222003

Schembri, S., \& Sandberg, J. (2003). Understanding service quality trough experience. 3rd International Conference on Critical Management Studies, 7-9 July, Lancaster University.

Schembri, S., \& Sandberg, J. (2011). The experiential meaning of service quality. Marketing Theory, 11(2), 165186. http://dx.doi.org/10.1177/1470593111403221

Setó, P. D. (2012). Total Quality Management \& Business Excellence, 23(11-12), 1257-1271. http://dx.doi.org/10.1080/14783363.2012.669551

Sureshchandar, G. S., Chandrasekharan, R., \& Kamalanabhan, T. J. (2001). Customer perception of service quality: A critique. Total Quality Management, 12(1), 111-124. http://dx.doi.org/10.1080/09544120020010138

Taylor, S. A., \& Cronin, J. J., (1994). An Empirical Assessment of the SERVPERF Scale. Journal of Marketing Theory and Practice, 2(4), 52-69.

Teas, R. K. (1993). Expectations, performance, evaluation and consumers' perceptions of quality. Journal of Marketing, 57(4), 18-24. http://dx.doi.org/10.2307/1252216

Teas, R. K. (1994). Expectations a comparison standard in measuring service quality: an assessment of a reassessment. Journal of Marketing, 58(1), 132-139. http://dx.doi.org/10.2307/1252257

Urban, W. (2009). Service quality Gaps and their role in service enterprises development. Technological and $\begin{array}{lllll}\text { Economic Development } & \text { of }\end{array}$ http://dx.doi.org/10.3846/1392-8619.2009.15.631-645

van der Wiele, T., van Iwaarden, J., Williams, R., \& Eldridge, S. (2011). A new foundation for quality management in the business environment of the twenty-first century. Total Quality Management \& Business Excellence, 22(5), 587-598. http://dx.doi.org/10.1080/14783363.2011.568264

Webb, D. (2000). Understanding customer role and its importance in the formation of service quality expectations. Service Industries Journal, 20(1), 1-21. http://dx.doi.org/10.1080/02642060000000001

Zeithaml, V. A. (1988). Consumer perceptions of price, quality and value: a means-end model and synthesis of evidence. Journal of Marketing, 52(3), 2-22. http://dx.doi.org/10.2307/1251446

Zeithaml, V. A., Berry, L. L., \& Parasuraman, A. (1988). Communication and control processes in the delivery of service quality. Journal of Marketing, 52(2), 35-48. http://dx.doi.org/10.2307/1251263

Zeithaml, V. A., Berry, L. L., \& Parasuraman, A. (1993). The nature and determinants of customer expectations of service. Journal of the Academy of Marketing Science, 21(1), 1-12. http://dx.doi.org/10.1177/0092070393211001

Zeithaml, V. A., Berry, L. L., \& Parasuraman, A. (1996). The Behavioral Consequences of Service Quality. Journal of Marketing, 60(2), 31-46. http://dx.doi.org/10.2307/1251929

Zeithaml, V. A., Bitner, M. J., \& Gremler, D. D. (2012). Services marketing: integrating customer focus across the firm (6th ed.). New York: McGraw-Hill.

Note

Note 1. According to our observations, deliberate choices of undersizing quality standards are also sometimes taken by firms' management.

\section{Copyrights}

Copyright for this article is retained by the author(s), with first publication rights granted to the journal.

This is an open-access article distributed under the terms and conditions of the Creative Commons Attribution license (http://creativecommons.org/licenses/by/3.0/). 